\title{
Mutants of Acinetobacter calcoaceticus NCIB 8250 Constitutive for the Mandelate Enzymes
}

\author{
By C. A. FEWSON, A. LIVINGSTONE* AND HEATHER M. MOYES $\dagger$ \\ Department of Biochemistry, University of Glasgow, Glasgow G12 8QQ
}

(Received 3 February 1978)

\begin{abstract}
Methods for isolating mutants of Acinetobacter calcoaceticus NCIB 8250 constitutive for the mandelate enzymes were compared. Non-inducing substrates were not available. Continuous culture gave no stable constitutive mutants. Alternate culture in inducing (L-mandelate) and non-inducing (L-glutamate) media led to the isolation of mutants mesoconstitutive for L-mandelate dehydrogenase and phenylglyoxylate carboxy-lyase, and hyperinducible for benzaldehyde dehydrogenase I. Screening of possible anti-inducers showed that 2-phenylpropionate was very effective; it was a competitive inhibitor of gratuitous induction by thiophenoxyacetate, and was used for the isolation of constitutive mutants. Some of the mutants were magnoconstitutive for L-mandelate dehydrogenase, phenylglyoxylate carboxylyase and benzaldehyde dehydrogenase I and could not be further induced; others had lower specific activities which could be increased by induction with phenylglyoxylate or thiophenoxyacetate. Similar constitutive mutants were derived from a mutant which lacked L-mandelate dehydrogenase.
\end{abstract}

\section{INTRODUCTION}

The 'mandelate enzymes', L-mandelate dehydrogenase, phenylglyoxylate carboxy-lyase (EC 4.1.1.7) and benzaldehyde dehydrogenase $I$, convert $L(+)$-mandelate into benzoate in Acinetobacter calcoaceticus NCIB 8250 (Livingstone \& Fewson, 1972). These enzymes appear to be co-ordinately controlled and are induced by phenylglyoxylate, the product of the first enzyme, or gratuitously induced by thiophenoxyacetate [(phenylthio)acetate] (Livingstone $\&$ Fewson, 1972). We required mutants of $A$. calcoaceticus constitutive for the mandelate enzymes both for physiological experiments (e.g. Beggs \& Fewson, 1977) and for genetic mapping. However, very few mutants with altered regulation of the mandelate enzymes have been reported for any micro-organism (Hegeman, 1966; Hegeman \& Root, 1976); for instance, in $A$. calcoaceticus NCIB 8250 , the only available regulatory mutants are blocked mutants such as NF2405 (Livingstone \& Fewson, 1972). This paper compares different methods for isolating constitutive mutants and describes the properties of some of those obtained. Some of these results have been reported in a preliminary form (Fewson \& Foote, 1976; Moyes \& Fewson, 1976).

\section{METHODS}

Organisms and growth media. Mutants were derived from A. calcoaceticus wild-type strain NCIB 8250 (Fewson, $1967 a, b$ ) and from mutant NF1408 (NCIB 10789) lacking L-mandelate dehydrogenase (Livingstone, 1970). Bacterial strains were maintained and media were prepared as described earlier (Kennedy \& Fewson, 1968 a, b; Livingstone et al., 1972; Cook, Beggs \& Fewson, 1975).

* Present address: Beecham Pharmaceuticals (U.K. Division), Clarendon Road, Worthing, West Sussex BN14 8QH.

$\dagger$ Present address: Department of Biochemistry, University of Aberdeen, Marischal College, Aberdeen AB9 1AS. 
Identification of constitutive mutants. A rapid test for L-mandelate dehydrogenase activity was based on the method described by Hegeman (1966). Possible mutants were inoculated into 5 mM-L-glutamate/salts medium ( $3 \mathrm{ml}$ ) in capped $6 \times \frac{5}{8}$ inch test tubes. The cultures were grown at $30^{\circ} \mathrm{C}$ for $48 \mathrm{~h}$ with occasional mixing. They were harvested by centifugation at $4000 \mathrm{~g}$ for $15 \mathrm{~min}$ at room temperature and washed by resuspension in basal medium $(5 \mathrm{ml})$; toluene $(5 \mu \mathrm{l})$ was added, and the suspensions were mixed for $15 \mathrm{~s}$ on a Whirlimixer and then left at room temperature or $27^{\circ} \mathrm{C}$ for at least $20 \mathrm{~min}$. 2,6-Dichlorophenolindophenol $(0.1 \mathrm{ml})$ and L-mandelate $(0.1 \mathrm{ml}, \mathrm{pH} 7.0)$ were added to give final concentrations of 67 and $500 \mu \mathrm{M}$, respectively. The suspensions were mixed, sometimes they were covered with liquid paraffin, and then they were left at room temperature. Decoloration was followed by eye. Control cultures of both induced and uninduced wild-type strain were always included.

Isolation of constitutive mutants. Enrichment by alternate culture was based on the method described by Cohen-Bazire \& Jolit (1953). Both spontaneous and mutagen-induced constitutive mutants were isolated. For the isolation of spontaneous mutants, the starting inoculum was prepared by adding $0 \cdot 1 \mathrm{ml}$ of a $24 \mathrm{~h}$ nutrient broth culture to $10 \mathrm{~mm}$-succinate/salts medium $(50 \mathrm{ml})$ in $250 \mathrm{ml}$ Erlenmeyer flasks, followed by growth for 12 to $15 \mathrm{~h}$ at $30^{\circ} \mathrm{C}$ on a rotary shaker (approx. $180 \mathrm{rev} \cdot \mathrm{min}^{-1}$ ). For the isolation of mutageninduced constitutive mutants, the starting inoculum was treated with $N$-methyl- $N^{\prime}$-nitro- $N$-nitrosoguanidine $\left(0 \cdot 1 \mathrm{mg} \mathrm{ml}^{-1}\right.$ in citrate buffer for $\left.30 \mathrm{~min}\right)$ as described by Livingstone et al. (1972). After washing, the bacteria were resuspended in basal medium at $30^{\circ} \mathrm{C}$. Both types of inocula $(2 \mathrm{ml})$ were added to $10 \mathrm{mM}$-L-glutamate/ salts medium $(50 \mathrm{ml})$ in $250 \mathrm{ml}$ Erlenmeyer flasks. The cultures were grown for $16 \mathrm{~h}$ at $30^{\circ} \mathrm{C}$ on the rotary shaker before being used as inocula $(5 \mathrm{ml})$ for $5 \mathrm{mM}$-L-mandelate/salts medium $(50 \mathrm{ml})$. These cultures were grown for $8 \mathrm{~h}$ at $30^{\circ} \mathrm{C}$ on the rotary shaker and then used as inocula $(0.5 \mathrm{ml})$ for $10 \mathrm{mM}$-L-glutamate/salts medium. Alternate growth on L-glutamate $(16 \mathrm{~h})$ and L-mandelate $(8 \mathrm{~h})$ was repeated for at least nine cycles. The final cultures were serially diluted 1 to 10 in basal medium. Portions $(0 \cdot 1 \mathrm{ml})$ containing approx. 100 bacteria were spread on nutrient agar plates. The colonies were grown at $30^{\circ} \mathrm{C}$ for $24 \mathrm{~h}$. One half of each colony was maintained by spreading it on another nutrient agar plate; the other half was inoculated into $5 \mathrm{mM}$-L-glutamate/salts medium $(3 \mathrm{ml})$ and tested for constitutive synthesis of $\mathrm{L}$-mandelate dehydrogenase as described above.

Constitutive mutants were also isolated by plating the parent strain on medium containing an anti-inducer. Portions of a $24 \mathrm{~h}$ nutrient broth culture, used undiluted or diluted 1 to 10 in basal medium, were spread on agar $(1.5 \%$, w/v) plates containing $2 \mathrm{~mm}$-2-phenylpropionate plus $2 \mathrm{~mm}$-phenylglyoxylate/salts medium. Presumptive mutant colonies appeared during $10 \mathrm{~d}$ incubation at $30^{\circ} \mathrm{C}$; they were cloned on 2-phenylpropionate plus phenylglyoxylate medium and then tested for constitutive synthesis of L-mandelate dehydrogenase.

Measurement of enzyme activities. Experiments in which enzyme activities were measured after growth in inducing or non-inducing media were carried out as described by Livingstone et al. (1972). Early measurements of enzyme activities were made with extracts prepared by ultrasonic disruption (Livingstone \& Fewson, 1972). For later determinations, bacteria treated with toluene were used (Beggs, Cook \& Fewson, 1976; Beggs \& Fewson, 1977); this method gave essentially the same results but was quicker, more convenient and economical. 'Benzoate oxidase' was measured with intact bacteria (Livingstone \& Fewson, 1972). Units of enzyme activity are defined as $\mu \mathrm{mol}$ substrate converted $\mathrm{min}^{-1}$.

Materials. All reagents were of the best grade that could be obtained commercially and, with the exception of Oxoid agar no. 1 and sodium phenylpyruvate from Sigma, were obtained from the sources listed by Livingstone \& Fewson (1972), Livingstone et al. (1972), Cook et al. (1975), Beggs et al. (1976) and Beggs \& Fewson (1977).

\section{RESULTS AND DISCUSSION}

\section{Non-inducing substrates}

We have not discovered any substrates that are not also inducers of the mandelate enzymes (see Kennedy \& Fewson, $1968 a, b$; Livingstone \& Fewson, 1972) and so could not use what is potentially the simplest method of isolating constitutive mutants (e.g. Brammar, Clarke \& Skinner, 1967). In any case, to make this method really effective, the non-inducing substrate must support growth after metabolism by the appropriate constitutive enzymes; this requirement is more restrictive for peripheral enzymes than for enzymes whose products feed fairly directly into an amphibolic pathway. 
Table 1. Enzyme activities in the wild type and mutant strains of A. calcoaceticus

Strains were grown for $2.5 \mathrm{~h}$ in L-glutamate/salts medium, with or without inducer. The inocula $(25 \%, \mathrm{v} / \mathrm{v})$ had been grown for 12 to $15 \mathrm{~h}$ in L-glutamate/salts medium. The bacteria were harvested, washed, stored and assayed as described in Methods. Values for the uninduced cultures are means \pm standard deviations and the values in parentheses indicate the number of experiments. Most other values are the means of two experiments.

\begin{tabular}{|c|c|c|c|c|}
\hline \multirow[b]{2}{*}{ Strain } & \multirow[b]{2}{*}{ Inducer } & \multicolumn{3}{|c|}{ Enzyme activities [munits (mg protein) ${ }^{-1}$ ] } \\
\hline & & $\begin{array}{l}\text { L-Mandelate } \\
\text { dehydrogenase }\end{array}$ & $\begin{array}{l}\text { Phenylglyoxylate } \\
\text { carboxy-lyase }\end{array}$ & $\begin{array}{l}\text { Benzaldehyde } \\
\text { dehydrogenase I }\end{array}$ \\
\hline Wild type & $\begin{array}{l}\text { None } \\
5 \text { mM-Phenylglyoxylate } \\
1 \text { mM-Thiophenoxyacetate }\end{array}$ & $\begin{array}{c}1 \cdot 10 \pm 0 \cdot 34(11) \\
190 \\
120\end{array}$ & $\begin{array}{c}2 \cdot 13 \pm 1 \cdot 09(8) \\
280 \\
200\end{array}$ & $\begin{array}{c}3 \cdot 80 \pm 1 \cdot 54(11) \\
36 \\
25\end{array}$ \\
\hline co4211 & $\begin{array}{l}\text { None } \\
5 \text { mm-Phenylglyoxylate } \\
1 \text { mm-Thiophenoxyacetate }\end{array}$ & $\begin{array}{c}6 \cdot 69 \pm 1 \cdot 27(8) \\
5 \cdot 1 \\
6 \cdot 2\end{array}$ & $\begin{array}{c}5 \cdot 58 \pm 0 \cdot 97(8) \\
9 \cdot 7 \\
5 \cdot 8\end{array}$ & $\begin{array}{c}3 \cdot 50 \pm 1 \cdot 35(8) \\
129 \\
33\end{array}$ \\
\hline HMM5 & $\begin{array}{l}\text { None } \\
1 \text { mM-Thiophenoxyacetate }\end{array}$ & $\begin{array}{l}407 \\
390\end{array}$ & $\begin{array}{l}754 \\
699\end{array}$ & $\begin{array}{l}72 \\
68\end{array}$ \\
\hline CF26 & $\begin{array}{l}\text { None } \\
5 \text { mm-Phenylglyoxylate }\end{array}$ & $\begin{array}{r}90 \\
165\end{array}$ & $\begin{array}{l}130 \\
\text { ND }\end{array}$ & $\begin{array}{l}\text { ND } \\
\text { ND }\end{array}$ \\
\hline CF8 & $\begin{array}{l}\text { None } \\
1 \text { mM-Thiophenoxyacetate }\end{array}$ & $\begin{array}{l}2 \\
2\end{array}$ & $\begin{array}{l}470 \\
522\end{array}$ & $\begin{array}{l}43 \\
56\end{array}$ \\
\hline CF27 & $\begin{array}{l}\text { None } \\
1 \text { mm-Thiophenoxyacetate }\end{array}$ & $\begin{array}{l}2 \\
2\end{array}$ & $\begin{array}{r}47 \\
190\end{array}$ & $\begin{array}{l}13 \\
35\end{array}$ \\
\hline
\end{tabular}

ND, Not determined.

\section{Continuous culture}

We isolated a few mutants from continuous cultures in which L-mandelate or phenylglyoxylate was the limiting substrate (specific growth rate 0.08 to $0.15 \mathrm{~h}^{-1}$ ). Two of those tested had low L-mandelate dehydrogenase activity [approx. 30 munits (mg protein) ${ }^{-1}$ ] in the absence of inducer. In the presence of inducer they had about the same activity as the wild type. None of these mutants was stable when stored in nutrient broth and we have not characterized them. Whilst one of the chief hazards of continuous culture is the selection of mutants, and this method is often supposed to be a good way of isolating constitutive mutants, in practice relatively few simple magnoconstitutive mutants of any micro-organism appear to have been isolated by this approach. This may be because there are many other ways of reacting to the selective pressure of nutrient limitation.

\section{Alternate culture on inducing and non-inducing substrates}

Almost 100 independent mutants were obtained by alternate culture in L-mandelate and L-glutamate media. Strains NE04071, NE02270 (both mutagen-induced) and co4211 (a spontaneous mutant; deposited in NCIB, accession no. 10786) were examined in detail; all were similar and the results in this paper were obtained with co4211.

Growth in the absence of inducer showed that L-mandelate dehydrogenase and phenylglyoxylate carboxy-lyase were mesoconstitutive, whereas there was only basal activity of benzaldehyde dehydrogenase I (Table 1). Other experiments showed no constitutive benzoate oxidase or catechol 1,2-oxygenase activities. Neither phenylglyoxylate (Table 1) nor L-mandelate further induced the first two enzymes, but benzaldehyde dehydrogenase I was hyperinduced. Benzyl alcohol dehydrogenase and benzaldehyde dehydrogenase II were exceptionally active under these conditions [specific activities of 554 and 399 munits (mg protein $)^{-1}$, respectively]; presumably sufficient benzaldehyde was formed for their induction, but insufficient phenylglyoxylate carboxy-lyase for repression (Beggs \& Fewson, 1977). The gratuitous inducer thiophenoxyacetate did not induce the first two enzymes, but induced benzaldehyde dehydrogenase I to about the same extent as in the wild type (Table 1). 


\section{Table 2. Prevention of induction of $\mathrm{L}$-mandelate dehydrogenase}

Acinetobacter calcoaceticus NCIB 8250 was grown for $2.5 \mathrm{~h}$ in $5 \mathrm{mM}-\mathrm{L}-$ glutamate plus 2 mM-phenylglyoxylate/salts medium, or in this medium supplemented with one of the compounds listed below (final concn $2 \mathrm{~mm}$ ). The bacteria were harvested, washed, treated with toluene and assayed as described in Methods. The specific activity after induction with phenylglyoxylate in the control culture was 240 munits (mg protein) ${ }^{-1}$.

\begin{tabular}{lclc}
\multicolumn{1}{c}{ Addition } & $\begin{array}{c}\text { L-Mandelate } \\
\text { dehydrogenase } \\
\text { activity } \\
\text { (\% of control) }\end{array}$ & \multicolumn{1}{c}{ Addition } & $\begin{array}{c}\text { L-Mandelate } \\
\text { dehydrogenase } \\
\text { activity }\end{array}$ \\
Atrolactate & 24 & 2-Phenoxyethanol & 129 \\
Atropate & 10 & 2-Phenoxypropionate & 11 \\
Benzenesulphinate & 82 & 3-Phenoxypropionate & 16 \\
Benzenesulphonate & 56 & DL-1-Phenylethanol & 117 \\
Benzilate & 15 & 2-Phenylethanol & 107 \\
DL-N-Benzoylalanine & 104 & N-Phenylglycine & 28 \\
3-Benzoylpropionate & 16 & 3-Phenyl-3-hydroxypropionate & 108 \\
Benzylmalonate & 121 & 3-Phenyl-L-lactate & 87 \\
4-Chlorophenoxyacetate & 32 & 2-Phenylpropionate & 1 \\
2,3-Dichlorophenoxyacetate & 24 & 3-Phenylpropionate & 8 \\
2,4-Dichlorophenoxyacetate & 7 & Phenylphosphonate & 89 \\
3,5-Dimethylphenoxyacetate & 65 & Phenylpyruvate & 83 \\
Mandelamide & 121 & Pyridylglycollate & 39 \\
2-Methoxyphenoxyacetate & 66 & Styrene glycol & 47 \\
2-Nitrophenoxyacetate & 82 & Tropate & 108 \\
4-Phenoxybutyrate & 16 & &
\end{tabular}

Mutant c04211 gave no detectable growth in liquid L-mandelate or phenylglyoxylate/salts media for at least a day, but grew at almost the same rate as the wild type (specific growth rate $0.45 \mathrm{~h}^{-1}$ ) in L-glutamate/salts medium. It formed faint colonies on L-mandelate/salts agar and this was the basis for enumeration of the mutant alone or in mixed culture with the wild type. When CO4211 or NE02270 was inoculated into $5 \mathrm{mM}-\mathrm{L}-\mathrm{mandelate} / \mathrm{salts}$ medium, growth usually occurred after about $2 \mathrm{~d}$. This was due to outgrowth of revertants, of which we isolated several independent strains. All the revertants tested grew at the same rate as the wild type in L-mandelate/salts medium. They were no longer constitutive for L-mandelate dehydrogenase or phenylglyoxylate carboxy-lyase, and all three mandelate enzymes were induced by phenylglyoxylate or thiophenoxyacetate to about the same extent as in the wild type.

Strain co4211 shows several phenotypic differences from the wild type, but it is possible that they are all the result of a single mutation. This is confirmed by the properties of the revertants. In some respects co4211 is reminiscent of the mutant of Pseudomonas putida isolated by Hegeman (1966) which was mesoconstitutive and superinducible for all the mandelate enzymes. Mutant co4211 resembles the second-stage mutant J8 which was isolated in separate experiments by quite different methods (Beggs \& Fewson, 1977) in that regulation of benzaldehyde dehydrogenase $\mathrm{I}$ is no longer co-ordinate with the first two enzymes. This suggests that while the mandelate enzymes are controlled as one regulon, different enzymes may be expressed independently because of a subordinate system of control such as separate operators.

In retrospect, it is clear that mutants like co4211 were enriched by alternate culture because they are well suited to grow in L-mandelate/salts medium along with the wild type. The mutants have very high activities of benzaldehyde dehydrogenases I and II under these conditions and can grow rapidly on the benzaldehyde accumulated by the wild type (Cook et al., 1975). This was confirmed by reconstitution experiments. When mixtures of co4211 and the wild type were inoculated into 2 mM-L-mandelate/salts medium, the mutant was 


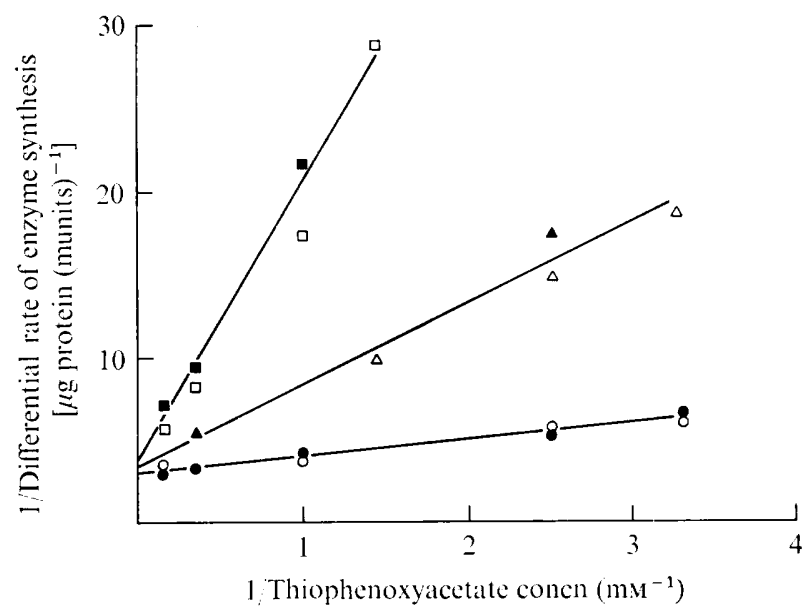

Fig. 1. Inhibition by 2-phenylpropionate of induction of L-mandelate dehydrogenase. Uninduced bacteria which had been grown in L-glutamate/salts medium were inoculated $(25 \%, \mathrm{v} / \mathrm{v})$ into 5 mML-glutamate/salts medium ( $80 \mathrm{ml}$ final volume in $250 \mathrm{ml}$ flasks) containing appropriate concentrations of 2-phenylpropionate $(O, O$, none; $\Delta, \Delta, 0.1 \mathrm{~mm} ; \boldsymbol{\nabla}, \square, 0.3 \mathrm{~mm}$ ) and thiophenoxyacetate. The flasks were shaken $\left(180 \mathrm{rev} . \mathrm{min}^{-1}\right)$ for $2 \mathrm{~h}$ at $30^{\circ} \mathrm{C}$. The bacteria were then harvested, washed and stored at $-20^{\circ} \mathrm{C}$. L-Mandelate dehydrogenase was measured after treatment of the bacteria with toluene. Measurements of $A_{500}$ were made at the beginning and end of growth so that the increase in bacterial protein could be determined (Cook et al., 1975). Differential rates of enzyme synthesis were calculated as [increase in L-mandelate dehydrogenase (munits $\mathrm{ml}^{-1}$ )]/[increase in bacterial protein $\left.\left(\mu \mathrm{g} \mathrm{ml}^{-1}\right)\right]$. Open and closed symbols represent two experiments.

enriched and less benzaldehyde accumulated. When we finally obtained mutants magnoconstitutive for the mandelate enzymes (e.g. HMM5, Table 1), we found that they were not enriched in reconstituted alternate cultures. This is consistent with the fact that they did not grow up before the wild type when inoculated into L-mandelate or phenylglyoxylate/salts medium, presumably because they still needed to induce all the enzymes required for metabolism of benzoate. Alternate culture may therefore not be a good method for isolating mutants magnoconstitutive for enzymes in the distal parts of metabolic pathways which involve several co-ordinately controlled groups of enzymes.

\section{Anti-inducers}

Several analogues of phenylglyoxylate, most of which were known to be unable to induce the mandelate enzymes (Livingstone \& Fewson, 1972), were tested as anti-inducers (Table 2). Many of them partially prevented induction of L-mandelate dehydrogenase by phenylgyloxylate, so it would appear that anti-induction is less specific than induction. We did not tets compounds which support growth since they would have been of no use for isolating constitutive mutants. Separate experiments with mutant NF1408 (which lacks L-mandelate dehydrogenase) showed that neither $\mathrm{L}(+)$ - nor $\mathrm{D}(-)$-mandelate was an anti-inducer. 2-Phenylpropionate was the most effective anti-inducer and was chosen for further study. It prevented growth on phenylglyoxylate but had relatively little inhibitory effect on growth on L-glutamate, did not itself support growth and, as far as could be ascertained, was not metabolized by $A$. calcoaceticus. 2-Phenylpropionate appeared to competitively inhibit induction by thiophenoxyacetate (Fig. 1; also unpublished results of A. Foote). It may be misleading to analyse the complex events of induction in intact bacteria in this way, but it is possible that these results indicate competition for a single site, such as a repressor. Further work will be needed to show whether feedback repression by benzoate (Cook et al., 1975; see also Higgins \& Mandelstam, 1972, for the same effect in Pseudomonas putida) is another example of this fairly non-specific anti-induction. 
We have sometimes observed induction of benzyl alcohol dehydrogenase by 2-phenylpropionate in the absence of benzyl alcohol or benzaldehyde, but this effect was not reproducible and we have not pursued it, although it may be relevant to the mechanism of reciprocal expression of phenylglyoxylate carboxy-lyase and benzyl alcohol dehydrogenase (Beggs \& Fewson, 1977).

Plating the wild type on salts agar containing 2 mM-phenylglyoxylate plus $2 \mathrm{~mm}-2$ phenylpropionate gave mutants able to grow in the presence of 2-phenylpropionate. They arose at a frequency of approx. $10^{-7}$, and this frequency could be increased by placing a crystal of $N$-methyl- $N^{\prime}$-nitro- $N$-nitrosoguanidine on the centre of each plate. In most experiments about one-fifth of the mutants were constitutive; presumably the others had gained some different property to allow them to grow on phenylglyoxylate in the presence of 2-phenylpropionate. Some were magnoconstitutive (Table 1; e.g. HMM5, deposited in NCIB accession no. 11339) and could not be further induced. Others (e.g. CF26) had lower constitutive activities of the mandelate enzymes, but could be further induced by phenylglyoxylate or thiophenoxyacetate. The enzyme activities of mutants like HMM5 were greater than for the wild type induced under the same conditions, but approximated to the highest activities obtained for the wild type in continuous culture with limiting phenylglyoxylate at a specific growth rate of approx. $0 \cdot 2 \mathrm{~h}^{-1}$ (C. A. Fewson, unpublished results). Other experiments showed that HMM5 was not constitutive for benzoate oxidase or catechol 1,2-oxygenase.

Similar constitutive mutants were derived from strain NF1408 (Table 1; CF8 and CF27), but as expected they lacked L-mandelate dehydrogenase.

The constitutivity of the three mandelate enzymes in mutants like HMM5 confirms other lines of evidence (Livingstone \& Fewson, 1972) that these three enzymes are co-ordinately controlled.

It seems probable that this is the most profitable method of obtaining mutants magnoconstitutive for enzymes of peripheral catabolic pathways, provided that a suitable antiinducer can be found.

Parts of this work were supported by grants from the Science Research Council, the Medical Research Council and the Royal Society.

\section{REFERENCES}

Beggs, J. D. \& Fewson, C. A. (1977). Regulation of synthesis of benzyl alcohol dehydrogenase in Acinetobacter calcoaceticus NCIB 8250. Journal of General Microbiology 103, 127-140.

Beggs, J. D., Cook, A. M. \& Fewson, C. A. (1976). Regulation of growth of Acinetobacter calcoaceticus NCIB 8250 on benzyl alcohol in batch culture. Journal of General Microbiology 96, 365-374.

Brammar, W. J., Clarke, P. H. \& Skinner, A. J. (1967). Biochemical and genetic studies with regulator mutants of the Pseudomonas aeruginosa 8602 amidase system. Journal of General Microbiology 47, 87-102.

Cohen-Bazire, G. \& Jolit, M. (1953). Isolement par sélection de mutants d'Escherichia coli synthétisant spontanément l'amylomaltase et la $\beta$ galactosidase. Annales de l'Institut Pasteur 84, 937-945.

Cook, A. M., Beggs, J. D. \& Fewson, C. A. (1975). Regulation of growth of Acinetobacter calcoaceticus NCIB 8250 on L-mandelate in batch culture. Journal of General Microbiology 91, 325-337.
Fewson, C. A. (1967a). The growth and metabolic versatility of the Gram-negative bacterium NCIB 8250 ('Vibrio 01'). Journal of General Microbiology 46, 255-266.

Fewson, C. A. $(1967 b)$. The identity of the Gramnegative bacterium NCIB 8250 ('Vibrio 01 '). Journal of General Microbiology 48, 107-110.

Fewson, C. A. \& Foote, A. (1976). Inhibition of induction of the mandelate regulon in Acinetobacter calcoaceticus NCIB 8250. Proceedings of the Society for General Microbiology 3, 177.

Hegeman, G. D. (1966). Synthesis of the enzymes of the mandelate pathway by Pseudomonas putida. III. Isolation and properties of constitutive mutants. Journal of Bacteriology 91, 1161-1167.

Hegeman, G. D. \& Root, R. T. (1976). The effect of a non-metabolizable analog on mandelate catabolism in Pseudomonas putida. Archives of Microbiology 110, 19-25.

Higgins, S. J. \& Mandelstam, J. (1972). Regulation of pathways degrading aromatic substrates in Pseudomonas putida. Enzyme response to binary mixtures of substrates. Biochemical Journal 126, 901-916. 
Kennedy, S. I. T. \& Fewson, C. A. (1968a). Enzymes of the mandelate pathway in bacterium NCIB 8250. Biochemical Journal 107, 497-506.

KenNedy, S. I. T. \& Fewson, C. A. (1968b). Metabolism of mandelate and related compounds by bacterium NCIB 8250 . Journal of General Microbiology 53, 259-273.

Livingstone, A. (1970). Induction and activity of the mandelate pathway enzymes in bacterium NCIB 8250. Ph.D. thesis, University of Glasgow.

Livingstone, A. \& Fewson, C. A. (1972). Regulation of the enzymes converting L-mandelate into benzoate in bacterium NCIB 8250 . Biochemical Journal 130, 937-946.

Livingstone, A., Fewson, C. A., Kennedy, S. I. T. \& ZATMAN, L. J. (1972). Two benzaldehyde dehydrogenases in bacterium NCIB 8250. Distinguishing properties and regulation. Biochemical Journal 130, 927-935.

Moyes, H. M. \& Fewson, C. A. (1976). Constitutivity of the mandelate enzymes in Acinetobacter calcoaceticus $\mathrm{NCIB} 8250$, and its effect on the synthesis of benzyl alcohol dehydrogenase. Biochemical Society Transactions 4, 1105-1106. 